\title{
Differentiation mechanisms of regeneration blastema cells during bone fracture healing
}

\author{
A. K. Popsuishapka ${ }^{1}$, V. A. Lytvyshko ${ }^{2}$, N. A. Ashukina ${ }^{3}$, \\ V. V. Hryhoriev ${ }^{4}$, O. A. Pidgaiska ${ }^{3}$
}

${ }^{1}$ Kharkiv Medical Academy for Postgraduate Education of the Ministry of Health of Ukraine

${ }^{2} \mathrm{CHI}$ «Kononenko Chuguyev Central District Hospital», Kharkiv region. Ukraine

${ }^{3}$ Sytenko Institute of Spine and Joints Pathology National Academy of Medical Sciences of Ukraine, Kharkiv

${ }^{4} \mathrm{CI}$ «Cherkasy City Emergency Hospital № 3». Ukraine

For understanding of reasons of bone nonunion after fractures we have to study the mechanisms which are on the base of cells differentiation. Objective: on the base of clinical and morphologic examination we studied the mechanisms of cells differentiation at regeneration process after shaft fractures. Methods: for histological study we took fibrin-blood clots from perifracture area and adjacent soft tissues in 25 patients after closed shaft fractures at open reduction. Biopsy samples of 9 patients were studied additionally with imunohistochemistry methods for the analysis of vessels endothelial growth factor and transforming growth factor- $\beta$ (TGF- $\beta)$. For assessment of fracture union we used $x$-rays. Results: in 1-5 days after trauma we have found fibrin-blood clots, where thickened fibrin partitions were located parallel to each other. Cells were formed by fibrin partitions, they had oval shape, it depicted the presence of fluid pressure inside of them. Expressed reaction on the vessels endothelial growth factorwas found in fibrin. During 7-18 days after fracture the fibrin-blood clot was reorganizes with formation of granular, soft tissue and osteogenic tissues. Expression of vessels endothelial growth factorand TGF- $\beta$ was registered in cells. Conclusions: osteogenic differentiation of mesenchimal cells in bone callous after the fracture can appear in case of coincide in time and space key factors - presence of fibrin matrix saturated vessels endothelial growth factor. It initiates vessels formation. Also there is need of close contact with alive mature tissues (bone, periosteum, muscles) which are the sources of slightly differentiated cells; tensions in fibrin-collagen blastema. Key words: bone shaft fracture, fibrin-blood clot, histology, immunohistochemistry, functional therapy.
Для понимания причин несращения кости после переломов, необходимо исследовать механизмы, лежащие в основе дифференциации клеток в регенерате. Цель: на основе клинических и морфологических исследований изучить механизмы клеточной дифференциачии в прочессе регенеращии после переломов длинных костей конечностей. Методы: для гистологического исследования у 25 пациентов из околоотломковой зоны выделены фибрин-кровяной сгусток и прилежащие мягкие ткани при открытом сопоставлении фрагментов после закрытых переломов диафизов длинных костей. Биопсийный материал 9 пациентов дополнительно изучен с помощью иммуногистохимических методов для анализа фактора роста эндотелия сосудов (VEGF) и трансформирующего фактора роста- $\beta$ (TGF- $\beta$ ). Для оченки сращения костных фрагментов использовали рентгенографию. Результаты: через 1-5 дней после травмы обнаружены участки фибрин-кровяного сгустка, где утолщенные фибриновые перегородки располагались параллельно друг другу. Ячейки, образованные фибриновыми перегородками, имели овально-вытянутую форму, что отражало наличие в них давления жидкости. Выраженная реакиия на VEGF обнаружена в фибрине. В течение 7-18 дней после перелома происходила реорганизачия фибрин-кровяного сгустка с образованием грануляционной, соединительной и остеогенной тканей. Экспрессия VEGF и TGF- $\beta$ зарегистрирована в клетках. Выводы: остеогенная дифференциация мезенхимальных клеток в регенерате после перелома кости может возникать в случае совпадения во времени и пространстве ключевых факторов - наличия фибринового матрикса, насыщенного VEGF, который инициирует образование сосудов; тесного контакта с жизнеспособными материнскими тканями (кость, периост, мыциы), которые являются источниками малодифференцированных клеток; напряженности в фибрин-коллагеновой бластеме. Ключевые слова: перелом диафиза, фибрин-кровяной сгусток, гистология, иммуногистохимия, функциональная терапия.

Key words: bone shaft fracture, fibrin-blood clot, histology, immunohistochemistry, functional therapy 


\section{Introduction}

Frequency of achievement of bone union of fragments should be deemed the efficiency criterion of the selected treatment strategy and tactics in fracture. Some fractures, following primary use of a certain treatment method, are not resolved via formation of osseous regenerate. An independent study [1], conducted using the data of insurance agency Thomson Reuters Marketscan (USA) for the year 2012, registering the expenses for treatment of fractures, has shown that, among 853 injured with shaft fractures of bones, repeated surgical intervention due to nonunion of fragments was performed in $12 \%$ of patients. Of these, it was carried out in $10 \%$ of closed fracture cases and $23 \%$ of open fracture cases.

To approach the understanding of the causes of bone nonunion after fractures, it is necessary to investigate the mechanisms underlying differentiation of regeneration blastema cells. It is known that, in case of nonunion of bone fractures, mainly connective tissue of different maturity degree with fibrocartilage elements is formed between them. At the same time, the connective tissue is not avascular [2-5]. The question why in some cases regeneration process occurs in the direction of connective tissue formation instead of osseous or cartilaginous one is the key issue. In particular, it should be mentioned that the formation of cartilaginous tissue sites in the regenerate is not the sign of disturbed process, as it is capable to transform into osseous one as far as vessels ingrow into it [6].

It has been established that osteogenic differentiation of cells is associated with angiogenesis $[7,8]$. Nevertheless, the newly formed connective tissue also contains many vessels. There is also a concept of osteogenic determination of poorly-differentiated stromal cells, originating from periosteum and endosteum [9], and the process direction is explained by their presence in inter-fragment area. Considerable package of publications is devoted to the family of bone morphogenetic proteins (BMP) [10]. But their absence or insufficient activity in the area where a regenerate has to form (close to the fragments) is not proven, and the authors suggest using them when the union has not occurred.

Objective: to investigate the cellular differentiation mechanisms during regeneration process after fractures of long limb bones on the basis of clinical and morphological studies.

\section{Materials and methods}

Histological studies. The materials for histological examinations were tissues around the fragments (in particular, fibrin-blood clot and adjacent soft tissues), which were removed during open reduction of fragment following closed shaft fractures of long bones in 16 injured: humerus -6 cases, tibia -5 , fibula -1 , femur -3 , radius -1 . Time after injury: 1 day -3 patients, $2-5$ days $-8,11-18$ days -5 . Biopsy materials of 9 patients (shaft fractures of tibia -2 , humerus -2 , forearm bones -4 , femoral bone -1 ; time elapsed since injury: $1-5$ days 4 cases, $8-12$ days -5 ), were additionally examined via immunohistological methods.

The obtained biopsy materials were fixed in $10 \%$ neutral formalin and treated in accordance with recommendations by D. S. Sarkisov and Yu. L. Perov. Prepared histological preparations were stained with hematoxylin and eosin (H\&E), and with picro-fuchsin according to Van Gieson's method [11].

Immunohistological method. Vascular endothelial growth factor (VEGF) and transforming growth factor $\beta$ (TGF- $\beta$ ) levels were measured in tissues surrounding the fragments. The preparations were made in Cherkasy Oblast Oncologic Dispensary with advisory aid of the head of histomorphological laboratory, anatomic pathologist M. F. Halkin. Following fixation in $10 \%$ buffered formalin, the material was treated in histoprocessor Mikrom CP-120. Prepared histological sections $(3 \mu \mathrm{m})$ were treated with mouse VEGF antibody (clone VGI) and polyclonal TGF- $\beta$ antibody (Diagnostic Bio Systems) via indirect peroxidase method with high-temperature antigen EnVision (Dako). The presence of examined factors was reflected by brown color.

All histological specimens were studied in the laboratory of connective tissue morphology of the Sytenko Institute of Spine and Joint Pathology (Kharkiv, Ukraine) under light microscope Olympus BX63, and photographed using digital camera DP73 (Olympus).

Bioethics requirements were met during the studies, which was confirmed by positive expert conclusions from the bioethics committee of the Sytenko Institute of Spine and Joint Pathology (Kharkiv, Ukraine) (meeting minutes № 109 dated 29.10.2012 and № 164 dated 18.04.2017).

Clinical and X-ray registration of loading effect on regenerate. We specially evaluated a patient group (7 subjects) with shaft fractures of long limb bones, who, following 2-4 months of immobilization of fragments and the absence of X-ray signs of osseous regenerate, had a change of loading regimen with occurrence of strains and deformation of tissues surrounding the fragments (table). Such situations included:

- fractures of metal fixators; 
- removal of external fixation apparatus with further limb loading in Delbet's plaster bandage;

- replacement of plaster immobilization of the whole injured limb with shortened orthosis with prescription of therapeutic loads.

The feature, typical of all these patients, was that their fractures were closed and belonged to degree I-II of fixation of fragments with adjacent soft tissues [12]. Open reduction was made initially only in 3 of these patients. Position of fragments was satisfactory, except for two patients, who still had their displacement across the width by a half of crosssection. The course of fracture healing was assessed by the way of evaluation of angular mobility of fragments and using X-ray radiography.

\section{Results and discussion}

Day 1-5 after fracture. Microscopic examination has shown that fibrin-blood clot has cellular structure formed by fibrin septa. Assemblage of erythrocytes and individual lymphocytes and leukocytes were contained between them. In literature sources, fibrinblood clot is interpreted as «a network of complexly interlaced fibrin fibers and blood cells, platelets, and blood plasma captured into it» $[13,14]$. To our opinion, fibrin fibers connecting with each other form solid partitions, which, in their turn, form closed cells of round-oval shape, containing erythrocytes and blood serum. In histological preparations, one can see cell walls in the form of fibrin partitions, which exceed erythrocyte diameter several times in terms of thickness (fig. 1, a, b). Another potentially important fact is that, in three-dimensional space, fibrin fibers form walls of closed chambers containing cells and fluid. When exposed to additional external loads (considering the fact that fluid is non-compressible), tensions appear in fibrin walls-partitions, which can play an essential role in cell differentiation process.

Examination of histological sections has revealed certain sites of fibrin-blood clots, where thickened fibrin partitions were located in parallel to each other, i. e. they were unidirectional, which, to our opinion, was the result of the effects of internal forces (tensions) with relevant vector (fig. 1, a). At the same time, the cells formed between these fibrin partitions, had oval-elongated shape, which reflects the presence of fluid pressure in them.

In the first days after fracture, mostly blood cells were observed in fibrin-blood clot area located at a distance from adjacent tissues (osseous, muscular, periosteum, endosteum). At immediate proximity from injured tissues, poorly-differentiated mesenchymal cells and fibroblasts (shown by arrows) penetrated into the clots (fig. 2).
A typical pattern was seen in histological sections of biopsy materials obtained from 4 patients in 1-5 days after fracture, as a result of VEGF immunohistochemical identification: fibrin partitions were most intensely colored brown (arrow) (fig. 3, a), which marked the fibrin-blood clot area against the background of adjacent soft tissues, where only endothelial vascular cells were stained (arrow) (fig. 3, b). It is known that VEGF concentrations in hematoma in fracture area can exceed this parameter in blood serum by a factor of 15 [14]. This is due to the fact that VEGF released from platelets, adjacent bone cells or immunocompetent cells, is inbuilt into fibrin backbone by the way of connection with fibrinassociated heparin $[15,16,17]$. Thus, fibrin matrix of fibrin-blood clot becomes a reservoir for VEGF.

Comparison of preparations treated via immunohistochemical method and stained with hematoxylin and eosin has revealed that VEGF was identified in maximal levels in walls of oval-elongated cells, i. e. fibrin partitions of considerable thickness (fig. 3, a). Besides, irregular color intensity was identified in fibrin-blood clot area itself (fig. 3, c), which reflects irregular VEGF distribution in it, which might impact further progression of events.

TGF visualization at early terms after fracture (day 1-7) in fibrin-blood clot was considerably different from VEGF: brown color was identified only in leukocytes contained in it, as we have described earlier [18].

As follows from the information described above, VEGF appears directly in fibrin during clot formation, which gives it an important role at early regeneration stages. It has been established that VEGF released from osteoblasts is a chemotactic agent for neutrophils [19]. Besides, it induces migration of monocytes and macrophages, which phagocytize neutrophils and synthesize angiogenic factors [20]. Thus, VEGF stimulates angiogenesis not only via direct effects on endothelial cells, but also indirectly through macrophages.

Day 7-18 after fracture. During this period, rearrangement of fibrin-blood clot occurs with formation of tissues: granulation, connective with large number of osteoblasts, and osteogenic, characterized by considerable density of cells (fig. 4). It should be mentioned that cells differed by phenotype within the regenerate area. We tried to classify them by attribution to fibro- or osteoblastic programmed differentiation and to establish the conditions in which a certain cell type is formed.

It has been revealed that cells resembling osteoblasts by phenotype (with roundish, apically located 

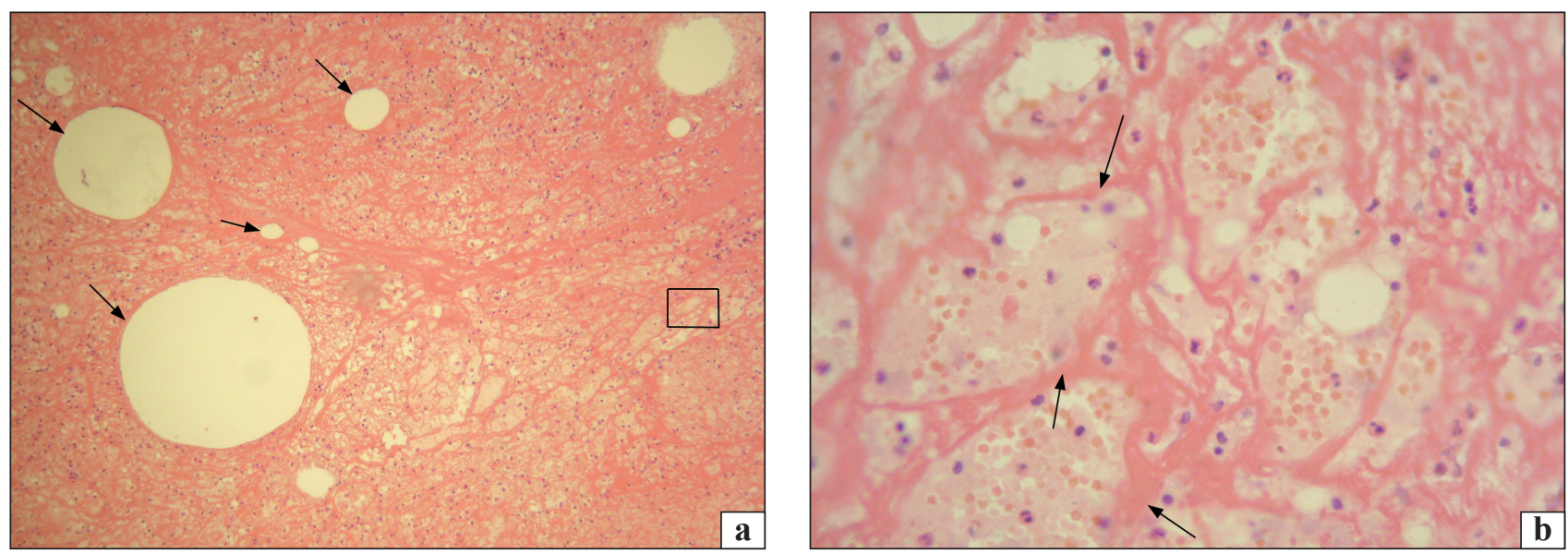

Fig. 1. A fragment of fibrin-blood clot from inter-fragment area, patient B., 41 years old, tibia fracture, day 4 after the injury: a) structure of fibrin partitions of the clot, choroid fissures (arrow), $\times 40$; b) fibrin partitions of the clot (arrow), forming close roundish chambers with blood cells, H\&E. $\times 400$
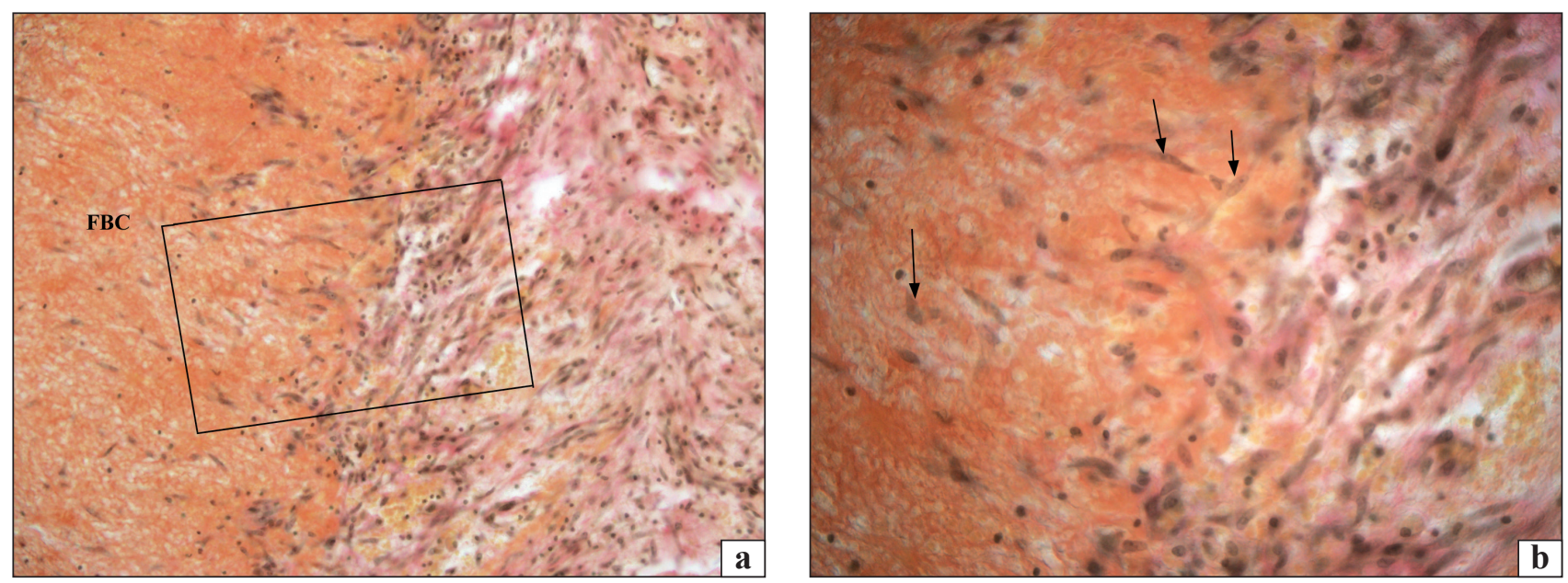

Fig. 2. Area surrounding the fragments of patient S., 45 years old, day 4 after femur fracture. Fibroblasts and poorly differentiated cells (arrow) in parent blood and in portion of fibrin-blood clot $(\mathrm{FBC})$ adjacent to it: a) $\times 200$; b) $\times 400$. Picro-fuchsin staining according to Van-Gieson
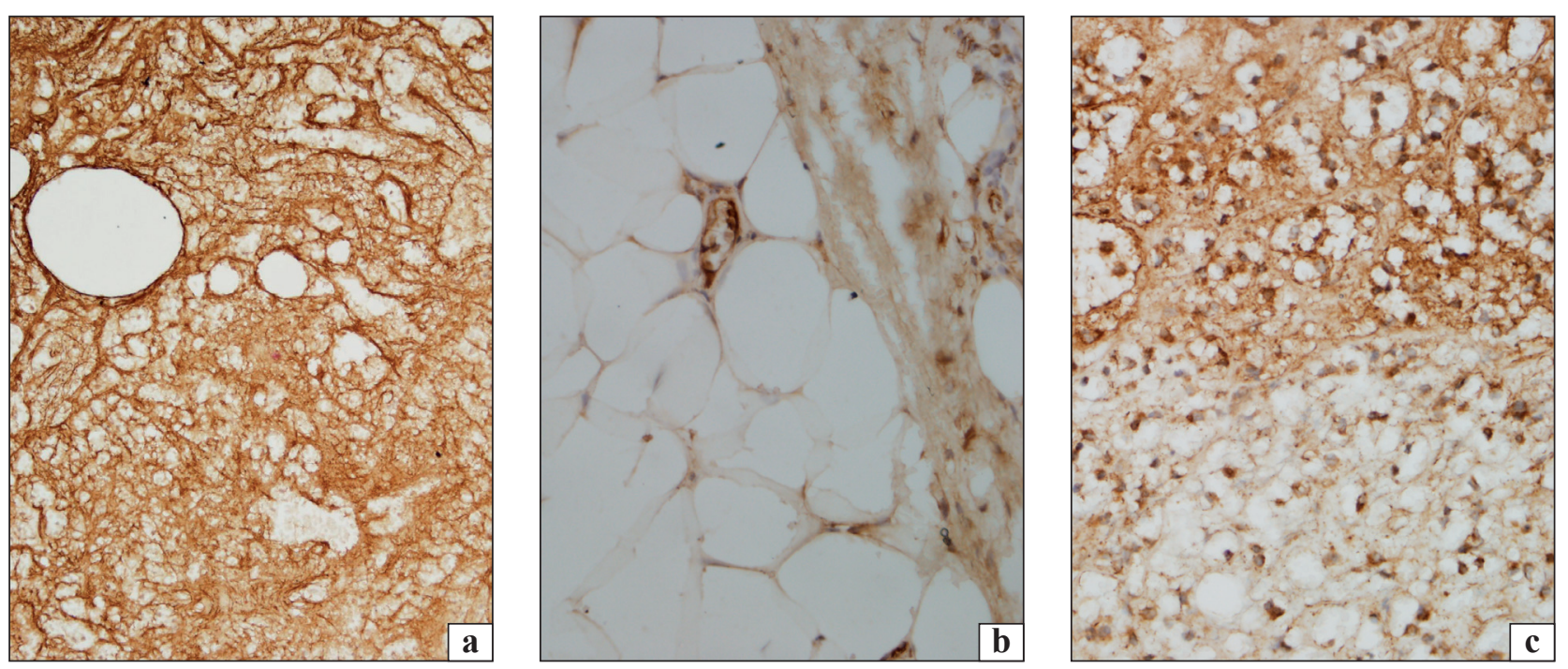

Fig. 3. Biopsy material from area surrounding the fragments, patient P., 54 years old first day after injury of forearm bone: a) intensive coloration of fibrin partitions of the clot; b) fragment of fibrin-blood clot with adjacent fatty tissue; c) irregular VEGF distribution in fibrin-blood clot. Immunohistochemical VEGF identification. $\times 200$ 

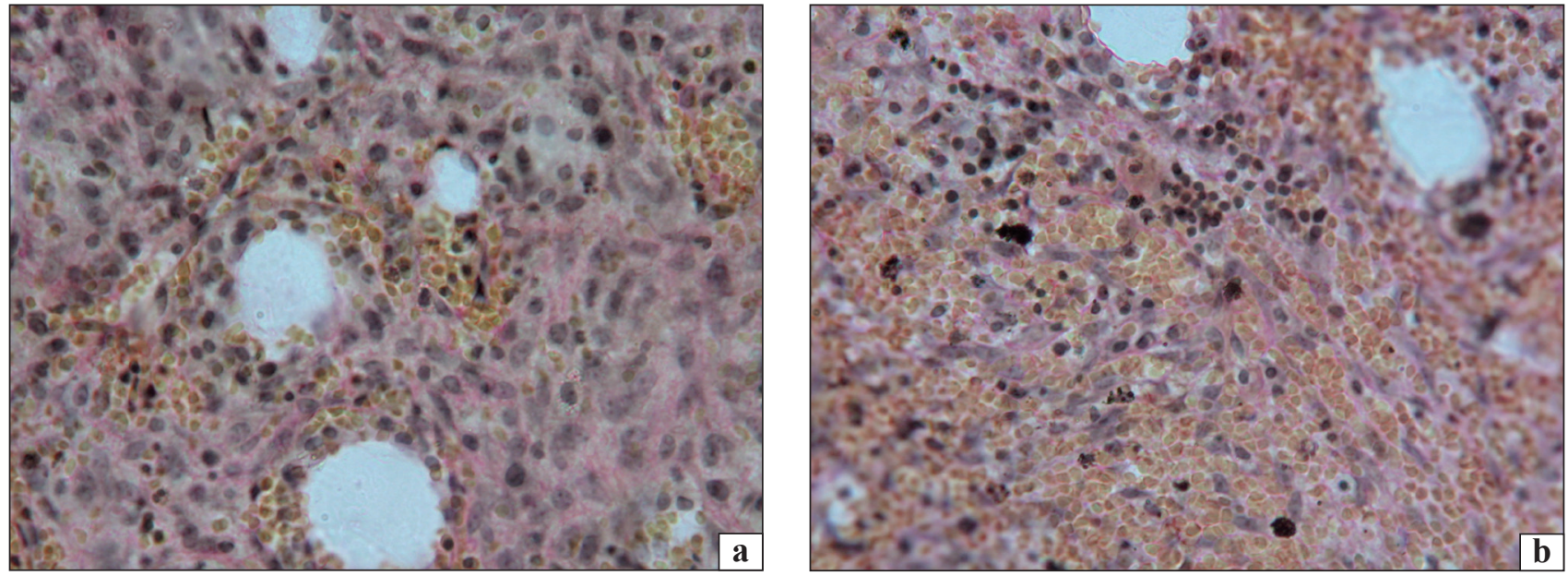

Fig. 4. Regeneration blastema fragments on day 12 after humerus fracture of patient O., 13 years old: a) osteogenic tissue with high density of osteoblasts around vessels; b) segregated fibroblasts in fibrin-blood clot residues. Picro-fuchsin staining according to Van-Gieson, $\times 400$

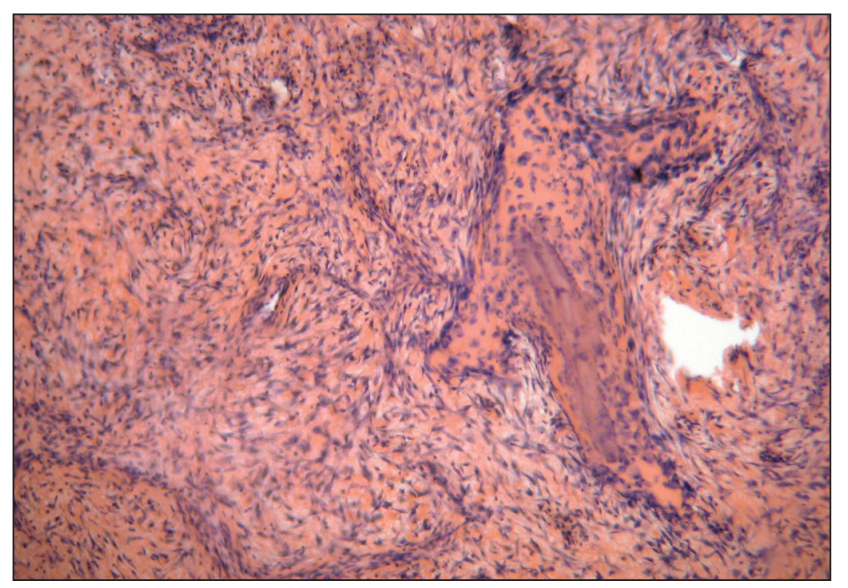

Fig. 5. A part of regenerate surrounding bone fragments in a patient K., 35 years old, 18 days after tibia fracture. Formation of new bone around osseous microfragment. H\&E, $\times 200$

hypochromic nuclei and developed basophilic cytoplasm) were found next to choroid fissures and capillaries (shown by arrows). Density of osteoblasts was high. Following reaction with picro-fuchsin according to Van Gieson, characteristic color matrix containing collagen was distinctly seen around them, i. e. osteoid was formed (fig. 4, a).

Areas where fibrin-blood clot residues were still seen contained fibroblasts - elongated cells with oval hypochromic nuclei, located at the cell center. Fibroblasts (marked by arrows) were located in parallel to each other and formed collagen fibers around themselves (fig. 4, b).

Formation of osseous trabeculas containing osteoblasts at the periphery was registered in two patients in 15 and 18 days following injury in fracture area. Newly formed trabeculas were surrounded by granulation tissue with considerable number of elongated fibroblastic cells. Their longitudinal axis was parallel to the axis of newly formed trabecula. This essential fact - coincidence of orientation directions of cells and trabecula - requires explanations. Trabecula is formed on the basis of collagen bundle already having a certain spatial orientation. Collagen fibers were synthesized by cells. But which ones? To our opinion, this function was performed at first by elongated spindle-shaped cells of fibroblastic type, which were oriented with their long axis along fibrin partitions, and collagen fibers agglomerated into bundles were arranged in the same manner. Collagen fiber is known to be formed on cell surface in parallel to its longitudinal axis [21]. Orientation of osteoblasts as affected by cyclic longitudinal deformations of the medium they are developed in has been studied in cell culture [22]. It has been established that majority of cells were oriented in the direction of force in the conditions of $12 \%$ stretching deformation. In case of $1 \%$ deformity, the cells were arranged in a chaotic way, and started aligning in one direction under the conditions of medium deformation exceeding $4 \%$. The sense of such cellular response is creation of structure effectively counteracting the external load, and, as can be seen from these results, development of such reaction requires a certain level of force irritation in the form of deformation or strain. Simply positional orientation of cells itself does not predetermine their differentiation yet. But we admit that formation of trabecula can occur through cooperation of two mechanocyte forms. At first, elongated spindle-shaped cells form collagen partition based on the fibrin one, and then oval cells (the ones we call osteoblasts) form osteoid on the collagen backbone. Now, all that remains is to find out 
Characteristics of clinical cases of shaft fracture in which periosteal ossification in response to delayed limb loading has been established

\begin{tabular}{|c|c|c|c|c|c|}
\hline $\begin{array}{l}\text { Patient's } \\
\text { initials }\end{array}$ & Age & Diagnosis & $\begin{array}{l}\text { Fragments fixation method } \\
\text { and treatment regimen }\end{array}$ & $\begin{array}{l}\text { Term and cause of limb loading } \\
\text { after fracture and regeneration area }\end{array}$ & Result \\
\hline L. & 20 & $\begin{array}{c}\text { Closed } \\
\text { transverse } \\
\text { fracture } \\
\text { of tibia bones }\end{array}$ & $\begin{array}{c}\text { External fixation device, } \\
\text { walking with crutches } \\
\text { without load }\end{array}$ & $\begin{array}{l}2.5 \text { months; the device is removed, } \\
\text { walking in plaster bandage } \\
\text { (Delbet type) with full load }\end{array}$ & $\begin{array}{l}\text { Appearance of osseous periosteal } \\
\text { regenerate, union in } 2.5 \text { months }\end{array}$ \\
\hline S. & 56 & $\begin{array}{l}\text { Closed torsion } \\
\text { fracture } \\
\text { of tibia bones }\end{array}$ & $\begin{array}{c}\text { Fixation with circular } \\
\text { plaster bandage, walking } \\
\text { without support }\end{array}$ & $\begin{array}{c}2 \text { months; replacement of plaster } \\
\text { bandage with Delbet type } \\
\text { bandage, walking with full load }\end{array}$ & $\begin{array}{l}\text { Appearance of osseous periosteal } \\
\text { regenerate in } 1 \text { month, } \\
\text { union in } 2.5 \text { months }\end{array}$ \\
\hline H. & 34 & $\begin{array}{l}\text { Closed torsion } \\
\text { fracture } \\
\text { of tibia bones }\end{array}$ & $\begin{array}{c}\text { External fixation device, } \\
\text { walking with crutches } \\
\text { without load }\end{array}$ & $\begin{array}{c}3.5 \text { months; started walking with } \\
\text { full support, fractures of rods } \\
\text { occurred }\end{array}$ & $\begin{array}{l}\text { Appearance of periosteal } \\
\text { regenerate, hyperplastic } \\
\text { nonunion has been formed }\end{array}$ \\
\hline L. & 50 & $\begin{array}{l}\text { Closed torsion } \\
\text { fracture } \\
\text { of tibia bones }\end{array}$ & $\begin{array}{l}\text { Osteosynthesis with } \\
\text { a plate, walking with } \\
\text { crutches without load }\end{array}$ & $\begin{array}{l}3 \text { months; started walking } \\
\text { with full support, fracture } \\
\text { of plate occurred }\end{array}$ & $\begin{array}{l}\text { Appearance of periosteal } \\
\text { regenerate, hyperplastic } \\
\text { nonunion has been formed }\end{array}$ \\
\hline H. & 19 & $\begin{array}{l}\text { Closed oblique } \\
\text { comminuted } \\
\text { fracture } \\
\text { of tibia bones }\end{array}$ & $\begin{array}{c}\text { External fixation device, } \\
\text { walking with crutches } \\
\text { without load }\end{array}$ & $\begin{array}{l}4 \text { months; the device has been } \\
\text { removed; fixation with Delbet } \\
\text { type bandage, walking } \\
\text { with full support }\end{array}$ & $\begin{array}{l}\text { Appearance of osseous periosteal } \\
\text { regenerate, union in } 2.5 \text { months }\end{array}$ \\
\hline V. & 48 & $\begin{array}{l}\text { Closed oblique } \\
\text { comminuted } \\
\text { fracture } \\
\text { of tibia bones }\end{array}$ & $\begin{array}{c}\text { External fixation device, } \\
\text { walking with crutches } \\
\text { without load }\end{array}$ & $\begin{array}{l}3 \text { months; the device has been } \\
\text { removed; fixation with Delbet } \\
\text { type bandage, walking } \\
\text { with full support }\end{array}$ & $\begin{array}{l}\text { Appearance of osseous periosteal } \\
\text { regenerate in } 3 \text { weeks, } \\
\text { union in } 3 \text { months }\end{array}$ \\
\hline M. & 68 & Shoulder bone & $\begin{array}{l}\text { Posterior plaster splint, } \\
\text { limb fixation to the chest }\end{array}$ & $\begin{array}{l}2 \text { months; fixation with orthosis } \\
\text { and prescription of functional load }\end{array}$ & $\begin{array}{l}\text { Appearance of osseous periosteal } \\
\text { regenerate, union in } 2 \text { months }\end{array}$ \\
\hline
\end{tabular}

the origin of these cells, but it will be done further, after presentation of several facts.

In one case (injury age 18 days) we observed the formation of new bone around osseous microfragment (indicated by an arrow), which was formed due to the fracture and appeared inside regenerate (fig. 5).

This fact is indicative of the presence of contact induction mechanism of specific cell differentiation. Non-differentiated cells start differentiating in accordance with tissue medium; here, special proteins, the ones now called bone morphogenetic proteins (BMP), exerts their effects. It looks like the information in this case is transferred via direct contact.

Observing the dimensions and configuration of fibrin partitions at early blastema stages, followed by formation of osteoid and trabecules, we have arrived to the assumption that osteogenesis can occur on the basis is massive (the thickest) fibrin-collagen partitions. Prerequisites for this process can include high concentration of angiogenic factor in them, which localizes angiogenesis in a targeted manner, as well as the condition of their strain. Partition orientation direction is a result of action of relevant internal force in it, and the thicker it is, the more durable it is, and the higher tension it can withstand without ruining. It is very likely that tension state of fibrincollagen masses is a factor of osteogenic differentia- tion of cells. At the same time, there must be a certain tension threshold, in which a non-differentiated cellmechanocyte recognizes the necessity in osteogenic differentiation direction.

We can confirm this assumption by our experience of functional treatment of fractures. For this purpose, we have selected clinical observations where, with limited function of injured limb and the absence of osseous regenerate signs, despite the long time elapsed since fracture, sudden change of fragments fixation regimen and functional activity with increase of tension effect on fragments occurred (table).

At the baseline, this patient group presented with 2-4-months old shaft fracture with satisfactory position of fragments, absence of periosteal osseous regeneration and presence of their angular mobility. They started treatment in other hospitals, and majority of them were prohibited to load the injured limb. Naturally, the absence of osseous regenerate within the specified terms caused anxiety and demanded the use of new therapeutic approaches. When the patients appeared to be under our control, targeted loading of fragments contact area was initiated via removal of the previous fixative, its replacement with functional plaster bandage or orthosis, and prescription of therapeutic exercise, walking with support on the limb. In two patients, the change 
of loading regimen of fragments contact site occurred due to fracture of the internal fixative, after they had started walking with support on the limb. In 1-1.5 months after the regimen modification, all patients showed the occurrence of periosteal osseous regenerate and elimination or decrease of angular mobility of fragments. Union of fragments was registered in 6 patients, and hypertrophic nonunion was formed in two patients, which was treated by the way of resection of splint bone site and elimination of deformation with external device. We emphasize that no regeneration stimulation measures, except for loading, were used in them.

\section{Clinical example}

An injured H., 34 years old, referred for medical aid due to deformation of tibia bone and pain during walking. Review of his history revealed that the patient had incurred closed torsion fracture of the left tibia bone due to ankle twisting (fig. 6, a).

At the previous treatment period the fragments were reduced on skeletal traction system, where he stayed for a month, after which the fragments were fixed with external apparatus, and the patient stared walking on crutches without support on the injured limb. X-ray radiography was performed in 2.5 months of such regimen, but nonunion was seen (fig. 6, b), and the patient was recommended to walk with support on the limb fixed with the device. Crus pain appeared after a month of loading, and X-ray radiography has shown that the rods were broken, and osseous regenerate appeared around the ends of fragments (fig. 6, c). This was registered in 4.5 months since the moment of fracture. The external device was removed, and the patient continued walking without additional support. The fragments were consolidated over time with varus deformity (fig. 6, d).

The available observations demonstrate the fact of formation of periosteal osseous regenerate in response to appearance of tension in tissue surrounding the fragments. It can be speculated that these patients already had blastema with the necessary set of mesenchymal cells and newly formed vessels, but the process of their differentiation in osteogenic direction occurred only as affected by tension.

The calculations we have performed by the method of finite element modeling have shown that tension areas appear in fibrin-periosteal spindle, and they are much larger in terms of dimensions and volume under the conditions of elastic fixation versus the rigid one [24].

Distinct and regular (arc-shaped as a rule) external contour of osseous regenerate is indicative of existence of a certain mechanical-morphological barrier between it and the surrounding soft tissues. We have seen in histological preparations that no osseous trabeculas appeared in viable surrounding soft tissues, in particular, muscular one, under the conditions of proliferative activity of mesenchymal cells in it as affected by blood infiltration. We believe that the cause of this phenomenon is heterogeneous medium, where different vital activity laws exist. Thus, osseous differentiation process occurs within the scope of namely fibrin-cell-collagen blastema, formed on the basis of fibrin-blood clot.

As we have observed, compact filling of fibrinblood clot with elongated, similar in shape mesenchymal cells occurs rather rapidly, but their difference in shape, conforming to fibroblast or osteoblast, starts showing itself approximately at the end of the second and the third day after the injury. The fact that osteoblasts are formed predominantly at certain sites is indicative of the fact that certain conditions are generated at these sites. These sites, as we have seen, were dense fibrin partitions with high VEGF expression. High concentration of this factor is known to be a driver of osteogenesis, which precedes and creates the conditions for osteogenic differentiation of cells in the relevant area. But this does not mean that the presence of sufficient blood supply of the relevant blastema area will immediately result in osteogenesis -
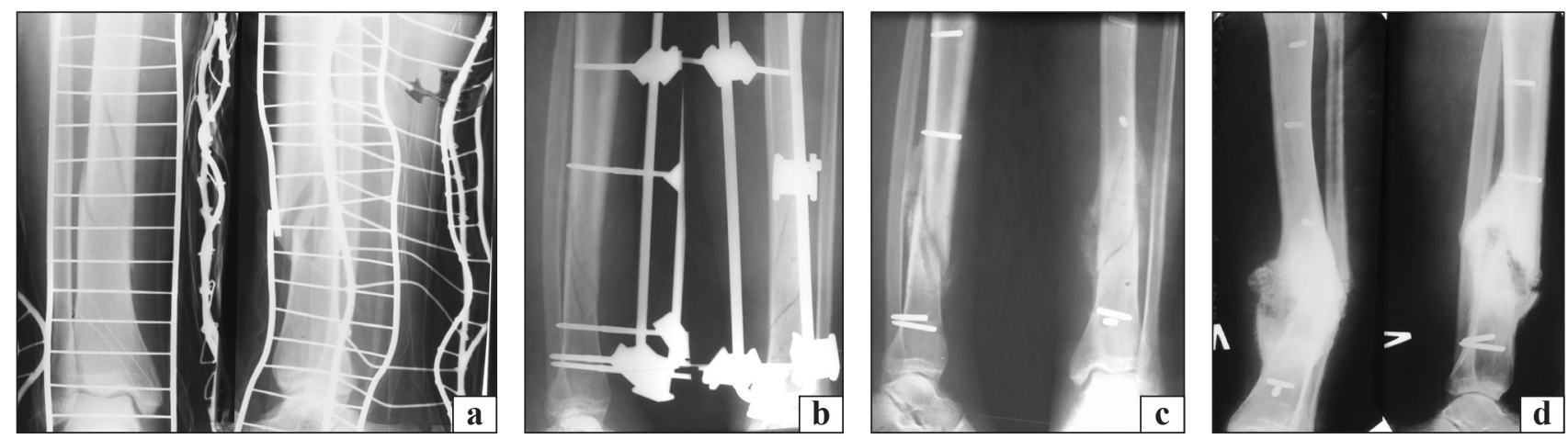

Fig. 6. X-ray radiographs of patient H., 34 years old, at treatment stages 
it can remain at granulated tissue stage. We believe that the factor guiding the process in osteogenic direction is response to tension of fibrin-collagen partition of sufficient level. The denser (more durable) the partition is, the higher tension it can bear, naturally deforming at the same time. Internal forces act on cellular cytoplasm and thus probably «inform» its functional differentiation, and probably activity level. The higher the pressure acting on it is, the more it has to counteract by the way of formation of supportive mechanical substance around itself, in order to protect itself against ruining (and this risk in such conditions is high). This concept is confirmed by the provided clinical fact of blastema ossification on month 3-4 of its exposure to strain.

Let us return to the issue of the origin of osteoblasts in regenerate. At least two relevant options can be discussed. The first one is existence of their predetermined pool, when they enter blastema from endosteum or periosteum [9]. According to the second option, all cells starting to fill a fibrin clot have equally poor differentiation, but their pluripotency is manifested as affected by conditions created in the medium, and they are differentiated as needed into the ones synthesizing collagen of certain type, and the ones subsequently forming osteoid on this collagen. We find more grounds for the second option.

\section{Conclusions}

On the basis of clinical and experimental studies it was proved that fibrin-blood clot which is formed in the first hours after shaft fracture played an important role in the further process of bone regeneration. It was determined that osteogenic differentiation of mesenchymal cells in regenerate after bone fracture can occur in case of time and space coincidence of the following key prerequisites:

- presence of fibrin backbone saturated with VEGF, which initiates and directs formation of vessels;

- its close contact with viable parent cells (bone and periosteal-muscular case), which are sources of mesenchymal non-differentiated cells;

- presence of tensions in fibrin-collagen blastema.

Suggested conception can promote us to revise the principles and approach for shaft fractures treatment. It means that we must preserve tissues that surround fracture area, fibrin-blood clot and have to create conditions for appearance of tensions in callous.

Conflict of interest. The authors declare the absence of conflict of interest.

\section{References}

1. Tibia shaft fractures: costly burden of nonunions / E. Antonova, T. K. Le, R. Burge, J. Mershon // BMC Musculoskeletal
Disorders. - 2013. - Vol. 14 (1). - Article ID : 42. DOI: $10.1186 / 1471-2474-14-42$.

2. Biological and molecular profile of fracture non-union tissue: current insights / M. Panteli, I. Pountos, E. Jones, P. V. Giannoudis // J. Cell. Mol. Med. - 2015. - Vol. 19 (4). P. 685-713. - DOI: 10.1111/jcmm.12532.

3. Morphological examination of biopsy materials from bone disregeneration areas / N. V. Dedukh, K. K. Romanenko, L. D. Horidova, N. A. Ashukina // Ukrainian Medical Almanac. - 2003. - Vol. 5, № 2. - P. 69-72.

4. Human atrophic fracture non-unions are not avascular/ A. A. Reed, C. J. Joyner, H. C. Brownlow [et al.] // J. Orthop. Res. - 2002. - Vol. 20 (3). - P. 593-599. — DOI: 10.1016/ S0736-0266(01)00142-5.

5. Human hypertrophic nonunion tissue contains mesenchymal progenitor cells with multilineage capacity in vitro / T. Iwakura, M. Miwa, Y. Sakai [et al.] // J. Orthop. Res. 2009. — Vol. 27 (2). - P. 208-215. — DOI: 10.1002/jor.20739.

6. Krompecher I. Local tissue metabolism and biological particulars of bone regenerate. Osseous tissue regeneration mechanisms / I. Krompecher : translated from eng. by A. M. Belousov, Ye. Ya. Pankov. - M. : Medicine, 1971. - 294 p.

7. Kanczler J. M. Osteogenesis and angiogenesis: the potential for engineering bone / J. M. Kanczler, R. O. Oreffo // Eur. Cell Mater. - 2008. - Vol. 15. - P. 100-114. DOI: $10.22203 /$ eCM.v015a08.

8. Angiogenesis in bone regeneration / K. D. Hankenson, M. Dishowitz, C. Gray, M. Schenker // Injury. - 2011. Vol. 42 (6). - P. 556-561. — DOI: 10.1016/j.injury.2011.03.035.

9. Oksymets V. M. Cellular-tissue technologies in treatment of reparative osteogenesis disorders and osseous tissue defects: theoretical justification and potential of clinical use (experimentaldiagnostic study) : Thesis for...Doctor of Medical Sciences : 14.01.21 / V. M. Oksymets. — Donetsk, 2014. - 338 p.

10. Moreno-Miralles I. New insights into bone morphogenetic protein signaling: focus on angiogenesis / I. Moreno-Miralles, J. C. Schisler, C. Patterson // Current Opinion in Hematology. - 2009. - Vol. 6 (3). — P. 195-201. — DOI: 10.1097/ moh.0b013e32832a07d6.

11. Sarkisov D. S. Microscopic Technique / D. S. Sarkisov, Yu. L. Perov. - M. : Medicine, 1996. - 542 p.

12. Lytvyshko V. O. The functional treatment of the diaphyseal tibial fractures using plaster cast or external fixator / V. O. Lytvyshko, O. K. Popsuishapka // Orthopaedics, Traumatology and Prosthetics. — 2015. — № 4. - P. 91-102. DOI: $10.15674 / 0030-59872015491-102$.

13. https://dic.academic.ru/dic.nsf/medic2/49113.

14. Alteration of blood clot structures by interleukin-1 beta in association with bone defects healing / X. Wang, T. E. Friis, P. P. Masci [et al.] // Scientific Reports. - 2016. - Vol. 6. Article ID : 35645 . — DOI: 10.1038/srep35645.

15. Is human fracture hematoma inherently angiogenic? / J. Street, D. Winter, J. H. Wang [et al.] // Clinical Orthopaedics and Related Research. - 2000. — № 378. - P. 224-237.

16. Heparin-binding domain of fibrin(ogen) binds growth factors and promotes tissue repair when incorporated within a synthetic matrix / M. M. Martino, P. S. Briquez, A. Ranga [et al.] // Proc. Natl. Acad. Sci. U S A. - 2013. — Vol. 110 (12). P. 4563-4568. — DOI: 10.1073/pnas.1221602110.

17. Mosesson M. W. Fibrinogen and fibrin structure and functions / M. W. Mosesson // J. Thromb. Haemost. — 2005. - Vol. 3 (8). P. 1894-1904. — DOI: 10.1111/j.1538-7836.2005.01365.x.

18. Hu K. The roles of vascular endothelial growth factor in bone repair and regeneration / K. Hu, B. R. Olsen // Bone. - 2016. Vol. 91. - P. 30-38. — DOI: 10.1016/j.bone.2016.06.013.

19. Localization of vascular endothelial growth factor and transforming growth factor- $\beta$ in tissues surrounding the fragment area after fractures of long limb bones in humans / V. V. Hry- 
horiev, O. K. Popsuishapka, N. O. Ashukina, F. M. Halkin // Orthopaedics, Traumatology and Prosthetics. - 2017. № 2. - P. 62-69. — DOI: 10.15674/0030-59872017262-69.

20. Hu K. Osteoblast-derived VEGF regulates osteoblast differentiation and bone formation during bone repair / K. Hu, B. R. Olsen // J. Clin. Invest. - 2016. - Vol. 126 (2). P. 509-526. - DOI: 10.1172/JCI82585.

21. Macrophage infiltration is associated with VEGF and EGFR expression in breast cancer / R. D. Leek, N. C. Hunt, R. J. Landers [et al.] // Journal of Pathology. - 2000. Vol. 190 (4). - P. 430-436. - DOI: 10.1002/(SICI)10969896(200003)190:4<430::AID-PATH538>3.0.CO;2-6.

22. Serov V. V. Connective tissue / V. V. Serov, A. B. Shekhter.
M. : Medicine, 1981. - $312 \mathrm{p}$

23. Effects of mechanical factors on the fracture healing process / L. E. Claes, C. A. Heigele, C. Neidlinger-Wilke [et al.] // Clinical Orthopaedics and Related Research. - 1998. № 335 (Suppl.) — P. S132-S147. — DOI: 10.1097/00003086199810001-00015.

24. Lytvyshko V. O. Strain-stress state of fibrin blood clot and periosteum in shaft fracture area under different conditions of fragments union, and its effect on structural organization of regenerate / V. O. Lytvyshko, O. K. Popsuishapka, O. V. Yaresko // Orthopaedics, Traumatology and Prosthetics. - 2016. — № 1. - P. 62-71. — DOI: 10.15674/003059872016162-71.

The article was received at editorial office 28.03.2018

\section{МЕХАНИЗМЫ ДИФФЕРЕНЦИАЦИИ КЛЕТОК РЕГЕНЕРАТОРНОЙ БЛАСТЕМЫ ВО ВРЕМЯ ЗАЖИВЛЕНИЯ ПЕРЕЛОМА}

А. К. Попсуйшапка ${ }^{1}$, В. А. Литвишко ${ }^{2}$, Н. А. Ашукина ${ }^{3}$, В. В. Григорьев ${ }^{4}$, О. А. Подгайская ${ }^{3}$

${ }^{1}$ Харьковская медицинская академия последипломного образования. Украина

${ }^{2}$ КУ «Чугуевская центральная районная больница им. М. И. Кононенко». Украина

${ }^{3}$ ГУ «Институт патологии позвоночника и суставов им. проф. М. И. Ситенко НАМН Украины», Харьков

${ }^{4}$ КУ «Черкасская городская больница скорой медицинской помощи № 3». Украина

Alexey Popsuishapka, MD, Prof. in Traumatology and Orthopaedics: alexecorn@gmail.com

$\triangle$ Valeriy Litvishko,PhD: 1vaort@yandex.ua

$\checkmark$ Nataliya Ashukina, PhD in Biol. Sci.: nataliya.ashukina@gmail.com

$\triangle$ Vitaliy Grigoryev: grigoriev.doc@gmail.com

$\triangle$ Olga Pidgaiska, PhD in Traumatology and Orthopaedics: podgayo@yahoo.com 